DOI: $10.1590 / 1809-6891 v 19 \mathrm{e}-51240$ MEDICINA VETERINÁRIA

\title{
BRACHIAL PLEXUS IN THE Leopardus geoffroyi
}

\section{PLEXO BRAQUIAL DO Leopardus geoffroyi}

\author{
Paulo Souza Junior ${ }^{1 *}$ \\ Julia Gabriela Wronski² \\ Natan Cruz Carvalho ${ }^{3}$ \\ Marcelo Abidu-Figueiredo ${ }^{4}$ \\ ${ }^{1}$ Universidade Federal do Pampa, Uruguaiana, RS, Brasil. \\ ${ }^{2}$ Universidade Federal do Rio Grande do Sul, Porto Alegre, RS, Brasil. \\ ${ }^{3}$ Universidade da Região da Campanha, Alegrete, RS, Brasil. \\ ${ }^{4}$ Universidade Federal Rural do Rio de Janeiro, Seropédica, RJ, Brasil. \\ *Corresponding author - paulosouza@unipampa.edu.br
}

\begin{abstract}
Six thoracic limbs from four Leopardus geoffroyi specimens were dissected in order to describe origin and distribution of nerves forming the brachial plexuses. The brachial plexus is a result of connections between ventral branches of the last four cervical nerves (C5, C6, C7 and C8) and the first thoracic nerve (T1). These branches are the origin of the suprascapularis, subscapularis, axillary, musculocutaneous, radial, median and ulnar nerves to the intrinsic musculature, and form the brachiocephalicus, thoracodorsal, lateral thoracic, long thoracic, cranial pectoral and caudal pectoral nerves to the extrinsic musculature. The $\mathrm{C} 7$ ventral branch is mainly responsible for formation of nerves (70.5\%), followed by C8 (47.4\%), C6 (29.5\%), T1 (19.2\%) and C5 (7.7\%). From 78 dissected nerves, $65.4 \%$ of nerves resulted from a combination of two or three branches, while only $34.6 \%$ of nerves originated from a single branch. Through comparison with other carnivoran species, the origin and innervation area of the Geoffroyi's Cat brachial plexus were most similar to those of the domestic cat, particularly among those nerves extended to the intrinsic musculature. The results of this study suggest that nerve block techniques currently used in dogs and cats might be efficient in Geoffroyi's Cat too.
\end{abstract}

Keywords: animal anatomy; Pampa's biome; wild carnivores; wild felines

\section{Resumo}

Seis membros torácicos de quatro espécimes de Leopardus geoffroyi foram dissecados para descrever a origem e a distribuição dos nervos formadores do plexo braquial. O plexo braquial resultou das conexões entre os ramos ventrais dos últimos quatro ramos ventrais cervicais $(\mathrm{C} 5, \mathrm{C} 6, \mathrm{C} 7$ e C8) e do primeiro torácico (T1). Estes ramos formaram os nervos supra-escapular, subescapular, axilar, musculocutâneo, radial, mediano e ulnar para os músculos intrínsecos e originaram os nervos braquiocefálico, toracodorsal, torácico lateral, torácico longo, peitoral cranial e peitoral caudal para os músculos extrínsecos. $\mathrm{O}$ ramo ventral de $\mathrm{C} 7$ foi o que mais contribuiu para a formação dos nervos do plexo (70,5\%), seguido por C8 (47,4\%), C6 (29,5\%), T1 (19,2\%) e C5 (7,7\%). Entre os 78 nervos 
dissecados, 65,4\% resultaram da combinação de dois ou mais ramos, enquanto apenas 34,6\% se originaram de um único ramo. Em comparação com outras espécies da ordem Carnivora, a origem e área de inervação do plexo braquial do gato-do-mato-grande se assemelhou mais com a do gato doméstico, especialmente no tocante aos nervos destinados à musculatura intrínseca. Os resultados do presente estudo sugerem que técnicas de bloqueio nervoso atualmente empregadas em cães e gatos podem ser também eficientes no gato-do-mato-grande.

Palavras-chave: anatomia animal, carnívoros silvestres, felinos silvestres, bioma Pampa.

Received on: January, $28^{\text {th }}, 2018$.

Accepted on: July, $5^{\text {th }}, 2018$.

\section{Introduction}

Leopardus geoffroyi (Geoffroyi's Cat) is a wild felid distributed in the area from Bolivia to that of extreme southern America ${ }^{(1)}$. It is a midsize species, weighing 2 to $6 \mathrm{~kg}$ and having length ranging from 78,1 to $95,6 \mathrm{~cm}^{(2,3)}$, with solitary behaviour and diet based on hares, small rodents and birds. $L$. geoffroyi shows a particular fur pattern with black speckles and spots, without rosettes, which differentiates it from other felids ${ }^{(1,2)}$. L. geoffroyi is listed with a status of 'Least Concern' because it is widespread and abundant over most of its above-mentioned range ${ }^{(3)}$.

Studying the thoracic limb morphology of carnivorans is important for understanding innumerable ecological variables, since the forelimbs act in the locomotion as well as in catching prey. Thus, morphology and function correlate to the prey type, locomotor apparatus and preference of habitat of the species ${ }^{(4)}$. Although research on limb miology is adequate for a functional understanding, knowledge of the nerves that innervate each muscle is essential for systematic analysis of locomotion physiology ${ }^{(5)}$.

In domestic mammals, the nerves of the brachial plexus are formed by a variable pattern of junctions between ventral branches of the sixth, seventh and eighth cervical spinal nerves (C6, C7 and C8), and by the first and second thoracic spinal nerves (T1 and $\mathrm{T} 2)^{(6,7)}$. Their fibres run across short distances and are distributed in variable combinations in order to supply the skin and muscles of the thoracic $\operatorname{limbs}^{(8)}$. Comparative studies of the brachial plexus between species have been developing since the $19^{\text {th }}$ century ${ }^{(9)}$. According to the study by Johnson et al. ${ }^{(10)}$, understanding the patterns and variations of the brachial plexus is still one of the most challenging areas in modern anatomy. Variations in the origins of the brachial plexus can be related to embryonic factors or can reflect phylogenetic features and features of evolution ${ }^{(11,12)}$. Furthermore, the anatomophysiological study of this plexus facilitates diagnosing neuromuscular dysfunctions ${ }^{(13)}$, and also guides loco-regional and plexus anaesthetic blocking techniques ${ }^{(14)}$.

For these reasons and because of the scarcity of anatomical studies in this species, the aim of this study was to describe origin and distribution of the main brachial plexus nerves of L. geoffroyi. 


\section{Materials and Methods}

Six brachial plexuses were evaluated (four from left antimer and two from right antimer) from four dead female specimens of $L$. geoffroyi that were collected from the roads of the south-western region of Rio Grande do Sul (SISBIO n³3667-1 authorisation). The cadavers were identified, fixed with subcutaneous, intramuscular and intracavitary injections of formaldehyde aqueous solution at $50 \%$, and then posteriorly preserved by immersion in opaque boxes with the same solution at $10 \%$. Posteriorly, after at least 14 days fixation, the six limbs were in ideal condition for studying and were dissected to evidence muscles as well as origin and branching of the nerves forming the brachial plexus. Then, after removing the skin and fascia, a medial incision was made through the pectoral musculature, which allowed exposure of the axillary area to facilitate dissecting the nerves individually. The nerves were named according to the ICGVAN ${ }^{(15)}$, except for the brachiocephalicus nerve, which was named according to Evans and DeLahunta ${ }^{(8)}$. Photomacrographic records were made by a digital camera (Sony Cyber Shot ${ }^{\circledR}$, DSC-S930, 10.1 MP) and schematic drawings were done illustrating origin of nerves and their distribution through comparing of different species.

\section{Results}

Macrodissections allowed the identification and schematisation of the components of L. geoffroyi's brachial plexus (Table 1). Five plexuses (83.3\%) from five specimens resulted from connections between ventral branches of the last four cervical nerves (C5, C6, C7 and C8) and first thoracic (T1) nerve; there was no participation of C5 in one (16.7\%) of the plexuses (left antimer). From these, suprascapularis, subscapularis, axillary, musculocutaneous, radial, median and ulnar nerves arose to the intrinsic musculature and brachiocephalicus, thoracodorsal, lateral thoracic, long thoracic, cranial and caudal pectoral nerves arose to the extrinsic musculature (Fig. 1). Schematic disposition of nerves and innervated muscles is illustrated on Fig. 2.

Considering all 13 nerves dissected on six different samples of branchial plexus $(n=78)$, it was observed that ventral branches of $\mathrm{C} 7$ were the main contributors to the formation of nerves $(70.5 \%)$, followed by C8 (47.4\%), C6 (29.5\%), T1 (19.2\%) and C5 (7.7\%). Altogether, 136 ventral branches formed 78 nerves, thus each nerve arose, on average, by the combination of practically two branches (1.74 branches/nerve). Nerves were monosegmental in 34.6\% cases and plurisegmental in $65.4 \%$ cases. The formation of nerve trunks was not recognised in the specimens of this current study. 
Table 1. Ventral branches distribution of brachial plexuses' origins from Leopardus geoffroyi

\begin{tabular}{|c|c|c|}
\hline Nerve & Origin (Frequency) & Innervated muscles \\
\hline Suprascapularis & $\begin{array}{l}\text { C6 }(n=3) \\
\text { C5 and C6 }(n=3)\end{array}$ & Supraspinatus and infraspinatus \\
\hline Subscapularis & $\mathrm{C} 6$ and $\mathrm{C} 7(n=6)$ & Subscapularis \\
\hline Musculocutaneous & $\begin{array}{l}\mathrm{C} 6 \text { and } \mathrm{C} 7(n=3) \\
\mathrm{C} 7(n=2) \\
\mathrm{C} 6(n=1)\end{array}$ & $\begin{array}{l}\text { Coracobrachialis, biceps brachii and } \\
\text { brachialis }\end{array}$ \\
\hline Axillary & $\begin{array}{l}\mathrm{C} 7(n=3) \\
\mathrm{C} 6 \text { and } \mathrm{C} 7(n=3)\end{array}$ & $\begin{array}{l}\text { Subscapularis, teres major, teres minor } \\
\text { and deltoideus (pars acromialis and } \\
\text { scapularis) }\end{array}$ \\
\hline Radial & $\begin{array}{l}\mathrm{C} 7, \mathrm{C} 8 \text { and } \mathrm{T} 1(n=4) \\
\mathrm{C} 7 \text { and } \mathrm{C} 8(n=2)\end{array}$ & $\begin{array}{l}\text { Tensor fasciae antebrachii, triceps } \\
\text { brachialis, anconeus and craniolateral } \\
\text { forearm muscles }\end{array}$ \\
\hline Median & $\begin{array}{l}\mathrm{C} 7, \mathrm{C} 8 \text { and } \mathrm{T} 1(n=3) \\
\mathrm{C} 7 \text { and } \mathrm{C} 8(n=3)\end{array}$ & $\begin{array}{l}\text { Pronator teres, flexor carpi radialis, flexor } \\
\text { digitorum profundus, flexor digitorum } \\
\text { superficialis and pronator quadratus. }\end{array}$ \\
\hline Ulnar & $\mathrm{C} 8$ and $\mathrm{T} 1(n=6)$ & $\begin{array}{l}\text { Flexor carpi ulnaris and flexor digitorum } \\
\text { profundus }\end{array}$ \\
\hline Brachiocephalicus & $\begin{array}{l}\text { C5 }(n=4) \\
\text { C6 }(n=2)\end{array}$ & Cleidobrachialis \\
\hline Long thoracic & $\mathrm{C} 7(n=6)$ & Serratus ventralis thoracis \\
\hline Thoracodorsal & $\begin{array}{l}\mathrm{C} 7 \text { and } \mathrm{C} 8(n=5) \\
\mathrm{C} 7(n=1) \\
\mathrm{C} 7 \text { and } \mathrm{C} 8(n=4)\end{array}$ & Latissimus dorsi \\
\hline Lateral Thoracic & $\begin{array}{l}\mathrm{C} 8 \text { and } \mathrm{T} 1(n=1) \\
\mathrm{C} 8(n=1) \\
\mathrm{C} 7(n=3)\end{array}$ & Pectoralis profundus and cutaneous trunci \\
\hline Cranial Pectoral & $\begin{array}{l}\mathrm{C} 7 \text { and } \mathrm{C} 8(n=2) \\
\mathrm{C} 6 \text { and } \mathrm{C} 7(n=1) \\
\mathrm{C} 7 \text { and } \mathrm{C} 8(n=4)\end{array}$ & Pectorales superficiales \\
\hline Caudal Pectoral & $\begin{array}{l}\mathrm{C} 8(n=1) \\
\mathrm{C} 8 \text { and } \mathrm{T} 1(n=1)\end{array}$ & Pectoralis profundus \\
\hline
\end{tabular}




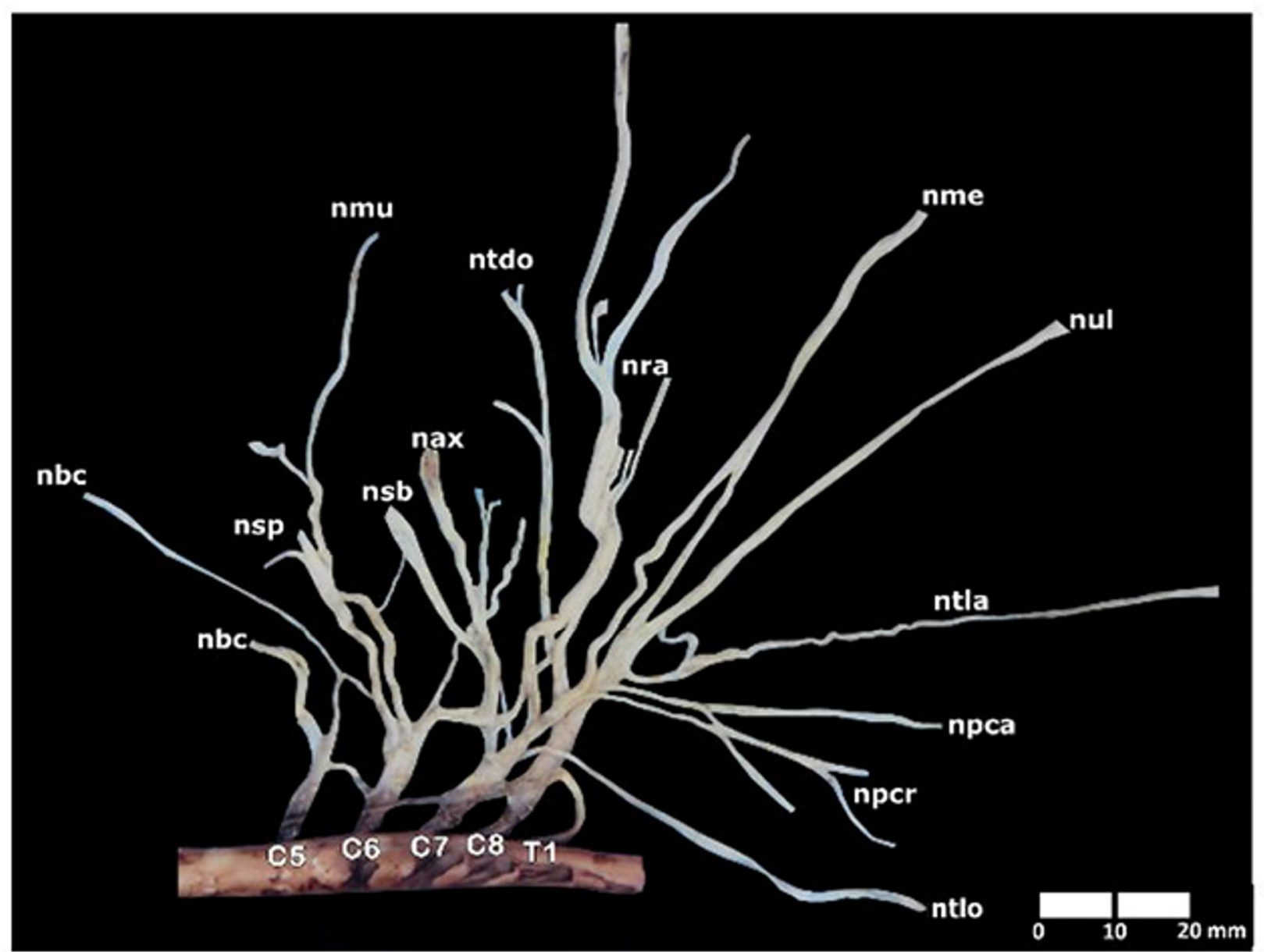

Figure 1. Photomacrograph of spinal cord, ventral spinal branches and left brachial plexus removed from an adult female Leopardus geoffroyi specimen. Spinal ventral branches of fifth (C5), sixth (C6), seventh (C7) and eighth (C8) cervical segments and first thoracic segment (T1). nax, axillary nerve; nbc, brachiocephalicus nerve; nme, median nerve; nmu, musculocutaneous nerve; npca, caudal pectoral nerve; npcr, cranial pectoral nerve; nra, radial nerve; nsb, subscapularis nerve; nsp, suprascapularis nerve; ntla, lateral thoracic nerve; ntlo, long thoracic nerve; ntdo, thoracodorsal nerve; nul, ulnar nerve 


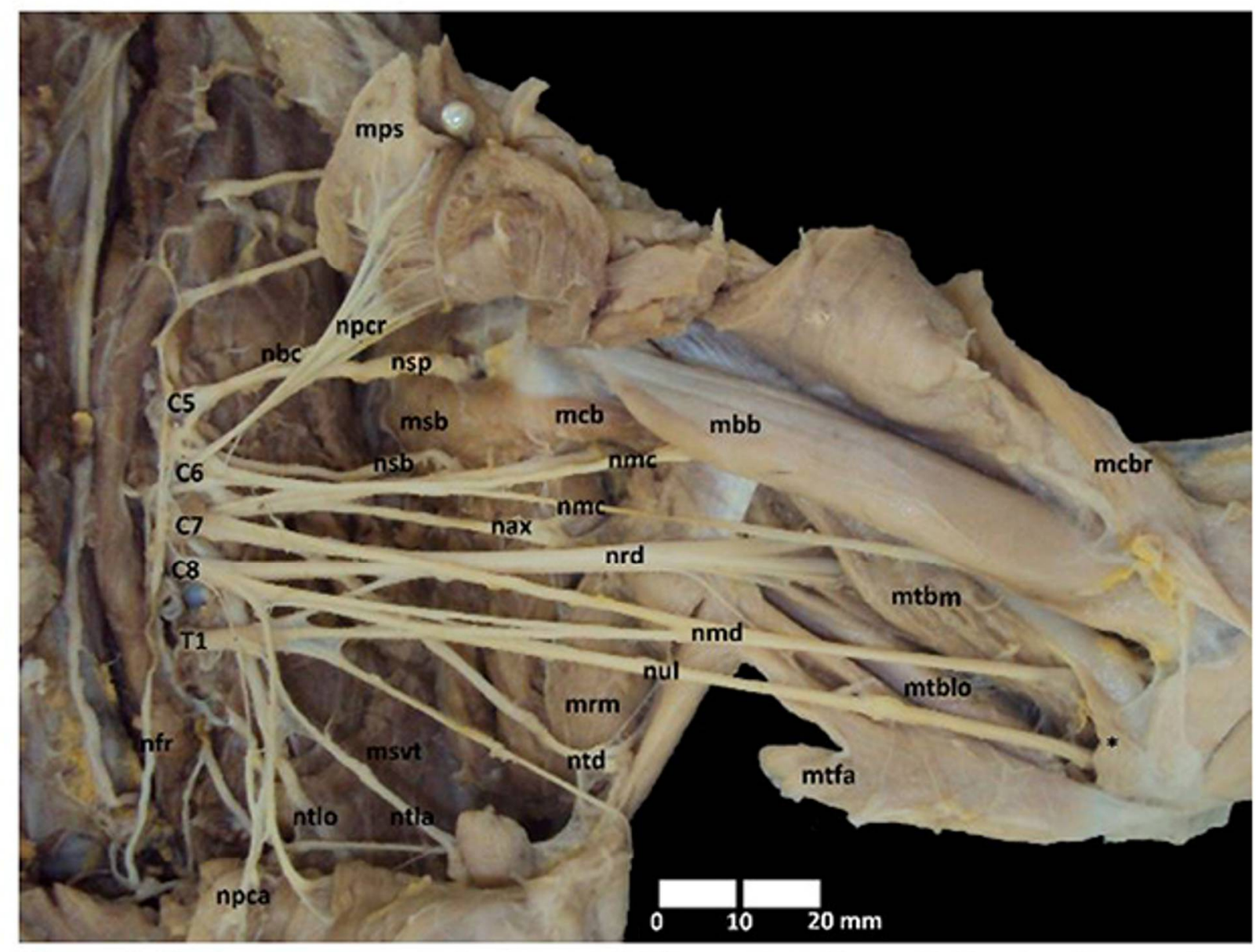

Figure 2. Photomacrograph of dissection of left thoracic limb, cervical and axillary regions, medial aspect, of a female adult Leopardus geoffroyi specimen. Ventral spinal branches of fifth (C5), sixth (C6), seventh (C7) and eighth (C8) cervical segments and first thoracic cervical segment(T1). mbb, biceps brachii muscle; mcb, coracobrachialis muscle; mcbr, cleidobrachialis muscle; mps, pectorales superficialis muscle; mrm, teres major muscle; msb, subscapularis muscle; msvt, serratus ventralis thoracis muscle; mtblo, long head of triceps brachii muscle; $\mathbf{m t b m}$, medial head of triceps brachii muscle; $\mathbf{m t f a}$, tensor fasciae antebrachii muscle; nax, axillary nerve; nbc, brachiocephalicus nerve; nfr, phrenic nerve; nmd, median nerve; nmc, musculocutaneous nerve; npca, caudal pectoral nerve; npcr, cranial pectoral nerve; nsb, subscapularis nerve; nsp, suprascapularis nerve; nrd, radial nerve; ntd, thoracodorsal nerve; ntla, lateral thoracic nerve; ntlo, long thoracic nerve; nul, ulnar nerve

\section{Discussion}

The brachial plexus of $L$. geoffroyi was formed essentially by ventral branches of five spinal nerves: C5; C6; C7; C8 and T1. Plexuses composed of at least five segments reflect versatile thoracic limbs which can act, for example, in scalation, excavation, running, swimming, food manipulation and catching of prey. Often these movements are made naturally by L. geoffroyi in its habitat. Mammals of other orders which have a brachial plexuses formed by at least five ventral branches include the 
monotremes $^{(16)}$, Myocastor coypus $^{(17)}$, Bradypus variegatus ${ }^{(18)}$, Bradypus torquatus $^{(19)}$, Hydrochaeris hydrochaeris (20), Agouti paca ${ }^{(21)}$, Tamandua tetradactyla(22), Myrmecophaga tridactyla(23), Sus scrofa $^{(24)}$ and human ${ }^{(25)}$ and non-human primates ${ }^{(26,27,28,29)}$. According to the study by Allam et al. ${ }^{(30)}$, a plexus formed by four ventral branches is characteristic of those species whose thoracic limbs are limited to supporting body weight and to specialised cursorial locomotion, and which are constitutively deprived of an ossified clavicle, such as, for example, canids and ungulates.

In Carnivora order, the contribution of $\mathrm{C} 5$ to the plexus was not reported for Leopardus pardalis ${ }^{(31)}$, and it was considered unusual (only $2.5 \%$ ) for domestic felines ${ }^{(32)}$. However, the dissections of these studies did not include the brachiocephalicus nerve. Allam et al. ${ }^{(30)}$ determined in their study that only $20.69 \%$ of the plexuses of domestic canines were formed between the $\mathrm{C} 5$ and $\mathrm{T} 1$ branches, illustrating the participation of $\mathrm{C} 5$ in forming the brachiocephalicus nerve, as observed for $L$. geoffroyi. For wild canines (specialised cursorial) such as Atelocynus microtis ${ }^{(33)}$, Cerdocyon thous ${ }^{(34)}$ and Lycalopex gymnocercus $^{(35)}$ and mustelids such as Martes foina ${ }^{(36)}$, the brachial plexus was restricted to four segments, being those between the C6 and T1 segments. For the procyonid Nasua nasua that uses the limbs for different functions, the plexus was also formed between the segments $\mathrm{C} 5$ and $\mathrm{T} 1^{(37)}$.

According to Ghoshal ${ }^{(38)}$ and Roos and Vollmerhaus ${ }^{(39)}$, thin contributions of T2 can occur in domestic felines. However, this was not alluded for domestic cat by Aubert et al. ${ }^{(32)}$, wild felids as $L$. pardalis by Chagas et al. ${ }^{(31)}$ and L. geoffroyi specimens in this study.

In the majority of cases, the most cranial point of origin of the brachial plexus of L. geoffroyi was the $\mathrm{C} 5$ ventral branch. Parada et al. ${ }^{(12)}$ proposed that the origin of this plexus migrated cranially during evolution, reaching $\mathrm{C} 4$ for some monkeys and even $\mathrm{C} 3$ for some humans individuals. Nevertheless, the presence of $\mathrm{C} 4$ forming the brachial plexus of Ornithorhynchus anatinus and Tachyglossus aculeatus $^{(16)}$, B. variegatus $^{(18)},{\text { B. } \text { torquatus }^{(19)} \text { and H. hydrochaeris }}^{(20)}$, among others, shows origin of brachial plexus in cranial branches is not a feature of recent species. These results give coherence to the hypothesis by Carpenter ${ }^{(11)}$, which suggests that variations in the most cranial origin of the plexuses result from the position of the insertion of limb buds compared to the neuro-axis of each species.

Some variations in the formation of nerves among antimers were verified in one specimen dissected. This was also usual for domestic felines ${ }^{(38)}$ and H. hydrochaeris $^{(20)}$. According to the study by Johnson et al. ${ }^{(10)}$, variations in neural architecture of brachial plexuses are very common. In a study with plexuses of 200 human foetuses, less than half presented a typical organisation, where variations prevailed $^{(40)}$.

For human and non-human primates $\left.{ }^{(10,41}\right)$, monotremes ${ }^{(16)}$, Hippopotamus amphibius ${ }^{(5)}$ and $B$. torquatus $^{(19)}$, for example, the trunk arrangement occurs as follows: superior or cranial; medial and inferior or caudal, with each trunk being a connection between nerves C5 and C6, C7, C8 and T1, respectively. For L. geoffroyi, there was no formation of such trunks, occurring very distinct branches origin, similar to domestic mammals ${ }^{(7)}$. The absence of the trunk is emphasised for domestic ${ }^{(30)}$ and wild canids ${ }^{(34,35)}$.

Among nerves that supply the intrinsic muscles of the thoracic limbs, those that end their innervation area proximal to the humeral-radial-ulnar joint (suprascapularis, subscapularis, axillary and musculocutaneous) had their origins concentrated in the cranial branches ( $\mathrm{C} 5, \mathrm{C} 6$ and $\mathrm{C} 7$ ) and were 
mostly monosegmental. The other nerves (radial, median and ulnar), which run to distal limb areas of the extensor and flexor muscles of the carpus and digits, had their origins concentrated in C7, C8 and $\mathrm{T} 1$ and were always plurisegmental. Thus, a largest contingent of nervous fibres to the complex musculature can be necessary, which move the elbow, carpus and digits, especially for felids, which depends on limb precision and strength for catching preys.

Ventral branches of $\mathrm{C} 7$ participated in forming $70.5 \%$ of nerves of the L. geoffroyi brachial plexus. Also, it was the branch that most originated the nerves of C. thous $(61.5 \%)^{(34)}$ and L. gymnocercus $(62.7 \%)^{(35)}$. Even though a small number of studies determined the participation percentage of each ventral branch, the findings in $L$. geoffroyi seems to repeat the anatomic patterns for domestic felids $^{(38)}$, L. pardalis $^{(31)}$, domestic $\operatorname{dog}^{(30)}, M$. foina ${ }^{(36)}$ and $N$. nasua ${ }^{(37)}$. It can be suggested that the central position of $\mathrm{C} 7$ among segments that originate the brachial plexus of these species would facilitate the fibres' distribution to a larger number of nerves.

The suprascapularis nerve of L. geoffroyi is formed invariably by C6, half of the suprascapularis nerve had contribution of C5. C6 participation in the forming of this nerve occurs in all species of the

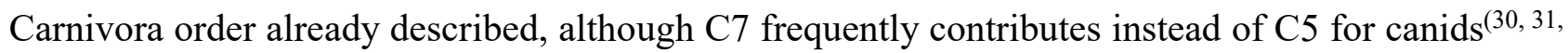
33-37, 42). Fioretto et al. ${ }^{(20)}$ have suggested that swimming species would have a suprascapularis nerve with broad plurisegmental origin (with three or even more branches). However, even for those carnivores with capacity for swimming, such as Arctocephalus australis and felids, generally the suprascapularis nerve is formed by two branches ${ }^{(31,38,42)}$. The suprascapularis nerve follows suprascapularis vessels, crossing medially at distal region between the subscapularis and supraspinatus muscle, where it branches to the last muscle. The nerve follows its tract surrounding medially the neck of the scapula, crossing to the lateral surface of the limb, where it innervates the infraspinous muscle. This innervation area is similar to the domestic dog ${ }^{(6,8,30)}$, domestic feline ${ }^{(38)}$,

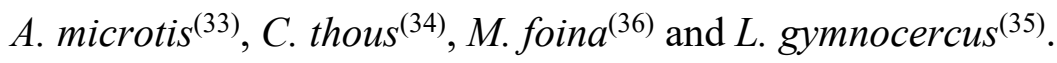

The subscapularis nerve is formed by ventral branches of C6 and C7 in all L. geoffroyi specimens. This origin agrees with all species described in the Carnivora order $(30,31,34 ; 35,36$ 37, 38), except for $A$. microtis $^{(33)}$, in which only C6 formed the subscapularis nerve, and for A $_{\text {australis }}{ }^{(42)}$, in which only $\mathrm{C} 7$ participated. This nerve presents two main branches, one cranial branch running all the way to the distal intermuscular region between subscapularis and teres major muscles, innervating them and one caudal innervating the teres major muscle. For domestic felines, this subscapularis nerve originates three branches and innervates also the latissimus dorsi muscle ${ }^{(38)}$.

The axillary nerve originates necessarily from $\mathrm{C} 7$, although the contribution of C6 occurs in half of the branchial plexuses. This origin agrees with what was described for domestic felines ${ }^{(38)}$ and $L$. pardalis $^{(31)}$, as well as for domestic $\operatorname{dog}^{(30)}$, A. microtis $^{(33)}$ and $M$. foina ${ }^{(36)}$. The nerve presents two portions, which transit between the caudoventral border of the subscapularis and teres major muscles, one of them sending branches to the last muscle. The second one passes to the lateral aspect of the limb, supplying the teres minor muscle as well as the acromial and scapular parts of the deltoid muscle. Except for the teres major muscle, this innervation area is similar to what was described for domestic felines ${ }^{(38)}$, Puma concolor and Panthera onca ${ }^{(43)}$, domestic $\operatorname{dog}^{(8)}$ and A. microtis $^{(33)}$.

The musculocutaneous nerve of L. geoffroyi arises from the ventral branches of C6 and C7, together or isolated. This constitution is similar to the majority of species from the Carnivora order studied, except for L. gymnocercus ${ }^{(35)}$, in which the contribution of C8 predominates, and for A. australis ${ }^{(42)}$, 
in which branches of $\mathrm{C} 8$ to $\mathrm{T} 1$ prevailed. The nerve forms delicate branches to the coracobrachial muscle and originates two main branches, one proximal to the biceps brachialis muscle and one distal

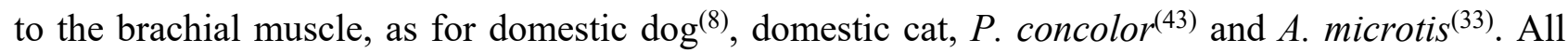
studied plexuses sent communicating branches to the median nerve, as for domestic $\operatorname{dog}^{(30)}$. This is functionally important because it allows the continuity of stimulus conduction even after injury in one of these nerves ${ }^{(44)}$. This junction is described as a common variation among humans ${ }^{(45)}$, and Iwamoto et al. ${ }^{(46)}$ in their study considered the analysis of this communication of branches essential for comparative studies between mammals.

The radial nerve originates predominantly from C7, C8 and T1 branches. This formation also prevails for domestic felids ${ }^{(38)}$ and L. pardalis ${ }^{(31)}$, as well as for domestic $\operatorname{dogs}^{(30)}, C$. thous ${ }^{(34)}$ and $L$. gymnocercus $^{(35)}$ and also for the otariid A. $_{\text {australis }}{ }^{(42)}$. In our results, there was no contribution of T1 for the canid $A$. microtis $^{(33)}$ and of $\mathrm{C} 7$ for the mustelid $M$. foina ${ }^{(36)}$. Thus, the radial nerve is the nerve having the major tendency of plurisegmentation of the Carnivora order due to its extensive area of motor and sensorial innervation.

The radial nerve's tract occurs at the medial aspect of the scapular region and crosses between long and medial heads of the triceps brachii muscle, emerging in the lateral aspect of the limb at the elbow level. It innervates all four heads of the triceps muscle, as well as anconeus and tensor of the antebrachial fascia muscles. Posteriorly, it divides into superficial and deep branches: the superficial branch passes through the lateral head of the triceps muscle and the brachial muscle, and then subdivides in two parts; one medial and one lateral, that follow the cephalic vein tract, passing over the brachioradialis muscle. From the lateral branch, the lateral cutaneous antebrachial nerve arises. The lateral portion is distributed to the hand and to the dorsal aspect of the digits, and the medial one is distributed to the medial aspect of the digit I. According to Arlamowska-Palider ${ }^{(47)}$, the presence of a well-developed cutaneous branch originating from the radial nerve is typical for inferior placental beings. For two evaluated limbs, the lateral cutaneous nerve of antebrachium branches to the brachioradialis muscle.

The deep branch of the radial nerve inserts itself between brachioradialis and the origin of the extensor carpi radialis muscle, innervating the first muscle and distributing to all craniolateral musculature of the antebrachium (extensor carpi radialis, extensor digitorum communis, extensor digitorum lateralis, ulnar lateralis, abductor digit I longus and supinator muscles). In general, the innervation area and branching of the radial nerve are similar to domestic feline ${ }^{(48)}, P$. concolor and $P$. onca ${ }^{(43)}$. The difference is for the last one; the medial splitting of superficial branching supplies the digit II, while the lateral supplies digit $\mathrm{III}^{(43)}$. Other carnivores in which the radial nerve contains the same motor

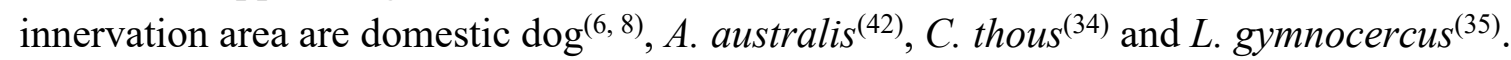

The median nerve emerges from two distinct branches; one from C7, and another from C8 and T1. The latter also originates the ulnar nerve. The nerve receives a communicating branch from the musculocutaneous nerve at the middle third of the limb in all plexuses and it runs with the ulnar nerve to the distal limb, where it crossed between long and medial head of triceps brachii muscle, reaching the supracondylar foramen. Then, it distributes to the caudal musculature of antebrachium (pronator teres, flexor carpi radialis, flexor digitorum profundus, flexor digitorum superficialis, flexor capri ulnaris and pronator quadratus muscles). Except for flexor ulnaris carpus, it has similar distribution of domestic feline ${ }^{(38)}$, P. concolor, P. onca ${ }^{(43)}$, domestic canids ${ }^{(30)}$, C. thous $^{(34)}$ and L. gymnocercus $^{(35)}$. 
The ulnar nerve origin for L. geoffroyi is C8 and T1, agreeing with virtually all of the Carnivora order (30, 31,33-38). Located caudally to the median nerve, the ulnar nerve dissociates from the median nerve in the middle third of the arm, passes above the medial epicondyle of the humerus and penetrates over the ulnar head of the flexor carpi ulnaris muscle, where it sends branches to the humeral head of the same muscle and to ulnar, humeral and radial heads of flexor digitorum profundus muscle, as for domestic cat $^{(38)}$, C. thous $^{(34)}$ and L. gymnocercus ${ }^{(35)}$.

L. geoffroyi's brachiocephalic nerve originated from C5 for the majority of plexuses, although originated from $\mathrm{C} 6$ in one plexus. The nerve exhibited a short path distally to rudimentary clavicle to innervate the cleidobrachialis muscle. Even if it is not listed at $\operatorname{ICGVAN}^{(15)}$, the nerve is included in this study for the authors who describe it in the plexuses of domestic carnivores ${ }^{(6,8,30,38)}$ and for $C$. thous $^{(34)}$, M. foina ${ }^{(36)}$ and L. gymnocercus ${ }^{(35)}$. In some cases, it was named as the subclavius nerve ${ }^{(31)}$. Predominance of $\mathrm{C} 5$ for brachiocephalicus nerve formation was also reported for domestic feline ${ }^{(38)}$. In domestic $\operatorname{dogs}{ }^{(30)}, C$. thous $^{(34)}, M$. foina ${ }^{(36)}$ and L. gymnocercus $^{(35)}$, the brachiocephalic nerve originated from C6, even if eventually from $\mathrm{C} 5$ in domestic dogs. For L. pardalis ${ }^{(31)}$, brachiocephalicus nerve was formed by $\mathrm{C} 6$ and $\mathrm{C} 7$. For Carnivora order, it seems to originate from the most cranial branch of the plexus.

Originating invariably from ventral branches of $\mathrm{C} 7$, the long thoracic nerve follows deeply to the scalenus muscles and to the lateral aspect of serratus ventralis thoracis muscle, innervating it. Its origin, tract and innervation area are similar to those of domestic carnivores ${ }^{(8,38)}$, C. thous ${ }^{(34)}$ and $L$. gymnocercus $^{(35)}$. For A. australis $^{(42)}$ and $M$. foina ${ }^{(36)}$, the long thoracic nerve also receives C8 contributions.

The thoracodorsal nerve arises predominantly from $\mathrm{C} 7$ and $\mathrm{C} 8$, also a characteristic that prevailed for domestic carnivores $^{(30,38)}, M$. foina ${ }^{(36)}$ and $N$. nasua ${ }^{(37)}$. For L. pardalis $^{(31)}$, it emerges from C8 and for A. australis it emerges from $\mathrm{C}^{(42)}$. Among wild canids, it originates between $\mathrm{C} 8$ and $\mathrm{T} 1{ }^{(33,34)}$, although for L. gymnocercus the C7 contribution was most frequent ${ }^{(35)}$. The nerve follows satellite

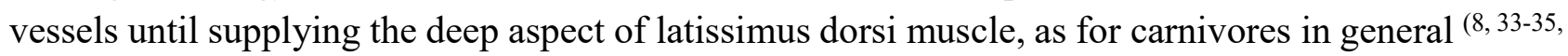
$38,42)$.

The lateral thoracic nerve is formed by $\mathrm{C} 7$ and $\mathrm{T} 8 \mathrm{in}$ most of the L. geoffroyi specimens, which agrees only with $M$. foina ${ }^{(36)}$. For the majority of species in Carnivora order, its origin predominates between $\mathrm{C} 8$ and $\mathrm{T} 1^{(30,34,35,38,42)}$, this configuration being found only in one plexus from this study. As for domestic felines ${ }^{(38)}$, it arose through the angle between the caudal border of triceps brachii and latissimus dorsi muscles, innervating the last and following the medial aspect of cutaneous trunci muscle, branching to thoracic and abdominal skin.

The cranial pectoral nerve of $L$. geoffroyi always has the ventral branch of $\mathrm{C} 7$ in its composition, even if eventually followed by $\mathrm{C} 6$ or $\mathrm{C} 8$. $\mathrm{C} 7$ participation for this nerve formation is very usual for Carnivora order, except for A. australis ${ }^{(42)}$, in which it originates by C6, and for L. gymnocercus ${ }^{(35)}$, in which $\mathrm{C} 7$ contribution is occasional. The caudal pectoral nerve originates always in $\mathrm{C} 8$, even if frequently receiving $\mathrm{C} 7$ contributions and, in one case, from $\mathrm{T} 1$. In fact, the ventral branch of $\mathrm{C} 8$ is described for caudal pectoral nerve origin in all plexus descriptions for Carnivora order, even if C7 and $\mathrm{T} 1$ also appeared although less frequently $(8,30,31,33-38,42)$. The innervation area of cranial pectoral nerve concentrates to the pectorales superficialis muscle, while the caudal one innervates the pectorals profundus muscle, as described for carnivores in general ${ }^{(8,30,31,33-38,42)}$. 


\section{Conclusions}

Comparing the description of other species with those of Carnivora order, greater similarity of brachial plexus origin can be observed. It can be inferred that similarities on plexus constitution among species from Carnivora order are concentrated on the nerves to intrinsic musculature of the thoracic limb. Given this similarity, it is suggested that the same anatomical landmarks used for anaesthetic loco-regional and blocks of brachial plexus of cats and dogs may be successfully employed for wild L. geoffroyi.

\section{Acknowledgements}

To Scholarship and Academic Development Program of Pró-reitoria de Assuntos Estudantis e Comunitários from UNIPAMPA, for the scholarship given to the second author.

\section{References}

1. Cubas ZS, Silva JCR, Catão-Dias JL. Tratado de Animais Selvagens. 1 ed. São Paulo, Roca; 2006. 1376p. Portuguese.

2. Oliveira TG, Cassaro K. Guia de identificação dos felinos brasileiros. 2nd ed. Sociedade de Zoológicos do Brasil: São Paulo. 1999. 60p.

3. Pereira J, Lucherini M, Trigo T. Leopardus geoffroyi. The IUCN Red List of Threatened Species 2015: e.T15310A50657011. Available from: http://dx.doi.org/10.2305/IUCN.UK.20152.RLTS.T15310A50657011.en.

4. Meachen-Samuels JA, Van Valkenburgh B. Forelimb indicators of prey-size preference in the Felidae. Journal of Morphology. 2009;270(6)729-744. http://dx.doi.org/10.1002/jmor.10712

5. Yoshitomi S, Kawashima T, Murakami K, Takayanagi M, Inoue Y, Aoyagi R, Sato F. Anatomical Architecture of the Brachial Plexus in the Common Hippopotamus (Hippopotamus amphibius) with Special Reference to the Derivation and Course of its Unique Branches. Anatomia Histologia Embryologia. 2012;41(4):280-285. http://dx.doi.org/10.1111/j.1439-0264.2012.01135.x

6. Ghoshal NG. Sistema Nervoso do Carnívoro: Nervos Espinhais. In: Getty R. Anatomia dos Animais Domésticos. 5th ed. Rio de Janeiro: Guanabara Koogan; 1986. p. 1595-1617. Portuguese.

7. Konig HE, Liebich HG. Anatomia dos Animais Domésticos: Texto e Atlas Colorido. 6th ed. Porto Alegre: Artmed, 2016. 824p. Portuguese.

8. Evans HE, DeLahunta A. Miller's Anatomy of the Dog. 4 ed. Philadelphia, Saunders Elsevier; 2013. 850p. English.

9. Paterson AM. The limb plexuses of mammals. Journal of Anatomy and Physiology. 1887; 21(4):611634.https://www.ncbi.nlm.nih.gov/pmc/articles/PMC1288693/pdf/janatphys00134-0089.pdf

10. Johnson EO, Vekris M, Demesticha T, Soucacos PN. Neuroanatomy of the brachial plexus: normal and variant anatomy on its formation. Surgical and radiologic anatomy. 2010; 32(3): 291-297.

https://doi.org/10.1007/s00276-010-0646-0 
11. Carpenter MB. Neuroanatomia Humana. $7^{\text {th }}$ ed. Rio de Janeiro: Interamericana; 1978. 574p. Portuguese.

12. Parada H, Pineda UH, Lagunas EM, Vudal HH. Variaciones anatômicas de las ramas raquídeas que constituyen los troncos de origen del plexo braquial. Anales Anatomía Normal. 1988;7:32-36.

13. Freeman PM, Harcourt-Brown TR, Jeffery ND, Granger N. Electrophysiologic evidence of polyneuropathy in a cat with signs of bilateral brachial plexus neuropathy. Journal of the American Veterinary Medical Association. 2009;234(2):240-244. https://doi.org/10.2460/javma.234.2.240

14. Futema F, Fantoni DT, Auler Junior JOC, Cortopassi SRG, Acaui A, Stopiglia AJ. Nova técnica de bloqueio do plexo braquial em cães. Ciência Rural. 1999.29(1):63-69. http://dx.doi.org/10.1590/S0103$\underline{84781999000100012}$

15. International Committee on Veterinary Gross Anatomical Nomenclature (ICGVAN). Nomina Anatomica Veterinaria. 6th ed. Hannover: Editorial Committee, 2017. 177 p. http://www.wavaamav.org/downloads/nav 6 2017.zip

16. Koizumi M, Sakai T. On the morphology of the brachial plexus of the platypus (Ornithorhynchus anatinus) and the echidna (Tachyglossus aculeatus). Journal of Anatomy. 1997; 190(3) 447-455. https://dx.doi.org/10.1046\%2Fj.1469-7580.1997.19030447.x

17. Taketani M. Comparative anatomy of the brachial plexus in Coypu (Myocastor coypus; Rodentia). Naturalistae. 2017;22:17-22. http://www1.ous.ac.jp/garden/kenkyuhoukoku/21/Naturalistae-2017feb-17$\underline{22 . p d f}$

18. Amorim Júnior AA, Amorim MJAAL, Silva DR, Andrade MB, Araújo FP, Pimentel DS, Alvim MMS, Rego PCNP, Origem do plexo braquial no bicho-preguiça (Bradypus variegatus, SHINZ,1825). 2002. Available from: http://www.sovergs.com.br/site/conbravet2002/259.htm

19. Cruz GAM, Adami M, Oliveira VL. Características anatômicas do plexo braquial de bicho-preguiça-decoleira (Bradypus torquatus Illiger, 1811). Biotemas. 2013;26(3):195-201. http://dx.doi.org/10.5007/2175$\underline{7925.2013 \mathrm{v} 26 \mathrm{n} 3 \mathrm{p} 195}$

20. Fioretto ET, Castro MFS, Guidi WL, Mainardi R, Souza RR, Ribeiro AACM. Gross anatomic organization of the capybara's (Hydrochaeris hydrochaeris) brachial plexus. Anatomia, Histologia, Embryologia 2003;32(3):169-174. http://dx.doi.org/10.1046/j.1439-0264.2003.00453.x

21. Scavone ARF, Machado MRF, Guimarães GC, Oliveira FS, Gerbasi SHB. Análise da origem e distribuição dos nervos periféricos do plexo braquial da paca (Agouti paca, Linnaeus, 1766). Ciência Animal Brasileira. 2008;9(4):1046-1055. https://revistas.ufg.br/vet/article/download/1100/4366

22. Cruz GAM, Adami M, Almeida AEFS, Silva EAAC, Faria MMMD, Pinto MGF, Silva RDG.

Características anatômicas do plexo braquial de tamanduá-mirim (Tamandua tetradactyla Linnaeus, 1758).

Revista Brasileira de Saúde e Produção Animal. 2012;13(3):712-719.

http://www.scielo.br/pdf/rbspa/v13n3/11.pdf

23. Souza PR, Cardoso JR, Araujo LBM, Moreira PC, Cruz VS, Araujo EG. Gross Anatomy of the Brachial Plexus in the Giant Anteater (Myrmecophaga tridactyla). Anatomia Histologia Embryologia.

2014;43(5):341-345. http://dx.doi.org/10.1111/ahe.12080

24. Santos LA, Silva FOC, Ribeiro LA, Borges TRJ, Silva DCO, Lizardo FB, Sousa GC, Carvalho-Barros RA. Origin and distribution of the brachial plexus in wild boar (Sus scrofa Linnaeus, 1758). Bioscience Journal. 2015;31(6):1816-1825. http://dx.doi.org/10.14393/BJ-v31n6a2015-29817

25. Guday E, Bekele A, Muche A. Anatomical study of prefixed versus postfixed brachial plexuses in adult human cadaver. ANZ J Surg. 2017;87(5):399-403. http://dx.doi.org/10.1111/ans.13534 
26. Cruz GAM, Adami M. Anatomia do plexo braquial de macaco-barrigudo (Lagothrix lagothricha). Pesquisa Veterinária Brasileira. 2010;30(10):881-886.

http://www.scielo.br/pdf/pvb/v30n10/a06v30n10.pdf

27. Santos Sousa CA, Gomes MS, Carvalho NC, Souza Junior P, Santos CM, Abidu-Figueiredo M. Origin and antimeric distribution of brachial plexus nerves in Macaca mulatta (Zimmermann, 1780) (Primates: Cercopithecidae). Italian Journal of Zoology. 2016; 83(4):469-481.

http://dx.doi.org/10.1080/11250003.2016.1258438

28. Zhang L, Dong Z, Zhang CL, Gu YD. Surgical anatomy of the radial nerve at the elbow and in the forearm: Anatomical basis for intraplexus nerve transfer to reconstruct thumb and finger extension in $\mathrm{C} 7$ T1 brachial plexus palsy. Journal of Reconstructive Microsurgery. 2016;32(9):670-674. http://dx.doi.org/10.1055/s-0036-1584687

29. Booth KK, Baloyi FM, Lukhele OM. The brachial plexus in the chacma baboon (Papio ursinus). J. Med. Primatol. 1997;26(4):196-203.http://dx.doi.org/10.1111/j.1600-0684.1997.tb00052.x

30. Allam MW, Lee DG, Nulsen FE, Fortune EA. 1952. The anatomy of the brachial plexus of the dog. The Anatomical Record. 1952;114(2):173-179.

31. Chagas KLS, Fé LCM, Pereira LC, Lima AR, Branco É. Descrição morfológica do plexo braquial de jaguatirica (Leopardus pardalis). Biotemas. 2014;27(2):171-176. http://dx.doi.org/10.5007/2175$7925.2014 \mathrm{v} 27 \mathrm{n} 2 \mathrm{p} 171$.

32. Aubert L, Carozzo C, Devillaire AC, Crevier-Denoix N, Moissonnier P. Macro and microanatomical characterization of the cat brachial plexus. Cells Tissues Organs 2004; 176(4):205-210.

https://doi.org/10.1159/000077037

33. Pinheiro LL, Branco ÉR, Souza DC, Souza ACB, Pereira LC, Lima AR. Descrição do plexo braquial do cachorro-do-mato-de-orelhas-curtas (Atelocynus microtis - Sclater, 1882): relato de caso. Biotemas.

2013;23(3)203-209. http://dx.doi.org/10.5007/2175-7925.2013v26n3p203

34. Souza Junior P, Carvalho NC, Mattos K, Santos ALQ. Origens e ramificações do plexo braquial no cachorro-do-mato Cerdocyon thous (Linnaeus, 1766). Pesquisa Veterinária Brasileira. 2014;34(10):10111023. http://www.scielo.br/pdf/pvb/v34n10/15.pdf

35. Souza Junior P, Carvalho NC, Mattos K, Abidu-Figueiredo M, Santos ALQ. Brachial Plexus in the Pampas Fox (Lycalopex gymnocercus): a Descriptive and Comparative Analysis. The Anatomical Record. 2017;300(3):537-548. http://dx.doi.org/10.1002/ar.23509

36. Demiraslan Y, Aykut M, Özgel Ö. Macroanatomical characteristics of plexus brachialis and its branches in martens (Martes foina). Turkish Journal of Veterinary and Animal Sciences. 2015;39:693-698.

http://dx.doi.org/10.3906/vet-1506-48

37. Felipe RL. Origem do plexo braquial e seus nervos em quatis (Nasua nasua Linnaeus, 1766). Dissertação apresentada ao Programa de Pós-graduação em Ciências Veterinárias da Faculdade de Medicina Veterinária da Universidade Federal de Uberlândia, Mestrado em Ciências Veterinárias. Uberlândia, MG, Brazil. 2014. Available from: https://repositorio.ufu.br/handle/123456789/13087

38. Ghoshal N, Magilton JH. The brachial plexus (Plexus brachialis) of the cat (Felis domestica). Anatomia Histolgia Embryologia. 1972;1(1):6-13. http://dx.doi.org/10.1111/j.1439-0264.1972.tb00947.x

39. Roos HH, Vollmerhaus B. Konstruktionsprinzipien an der Vorder- und Hinterpfote der Hauskatze (Felis catus). 4. Mitteilung: Muskelinnervation und Bewegungsanalyse. Anatomia, Histologia, Embryologia. 2005;34(1):2-14.http://dx.doi.org/10.1111/j.1439-0264.2004.00562.x

40. Uysal II, Seker M, Karabulut AK, Büyükmumcu M, Ziylan T. Brachial plexus variations in human

Cienc. anim. bras., Goiânia, v.19, 1-14, e-50805, 2018 
fetuses. Neurosurgery. 2003;53(3):676-684. https://doi.org/10.1227/01.NEU.0000079485.24016.70

41. Kikushi Y, Oishi M, Shimizu D. Morphology of brachial plexus and axillary artery in bonobo (Pan paniscus). Anatomia, Histologia, Embryologia. 2011.40(1)68-72. https://doi.org/10.1111/j.1439$\underline{0264.2010 .01040 . \mathrm{x}}$

42. Souza DAS, Castro TF, Franceschi RC, Silva Filho RP, Pereira MAM. Formação do plexo braquial e sistematização dos territórios nervosos em membros torácicos de lobos marinhos Arctocephalus australis. Brazilian Journal of Veterinary Research and Animal Science. 2010;47(2):168-174. http://dx.doi.org/10.11606/issn.1678-4456.bjvras.2010.26842

43. Sánchez HL, Silva LB, Rafasquino ME, Mateo AG, Zuccolilli GO, Portiansky EL, Alonso CR. Anatomical study of the forearm and hand nerves of the domestic cat (Felis catus), puma (Puma concolor) and jaguar (Panthera onca). Anatomia, Histologia, Embryologia. 2013;42(2):99104.http://dx.doi.org/10.1111/j.1439-0264.2012.01170.x

44. Sharp JW, Bailey CS, Johnson RD, Kitchell RL. Spinal Nerve Root Origin of the Median, Ulnar and Musculocutaneous Nerves and their Muscle Nerve Branches to the Canine Forelimb. Anatomia Histologia Embryologia. 1990;19(4):359-368. http://dx.doi.org/10.1111/j.1439-0264.1990.tb00911.x

45. El Falougy H, Selmeciova P, Kubikova E, Stenova J, Haviarova Z. The variable communicating branches between musculocutaneous and median nerves: a morphological study with clinical implications. Bratislavske Lekarske Listy. 2013;114(5):290-294. http://dx.doi.org/10.4149/BLL 2013061

46. Iwamoto S, Kimura K, Takahashi Y, Konishi M. Some Aspects of Communicating Branch of the Musculocutaneous and Median Nerves in Man. Okajimas Folia Anatomica Japonica. 1990;67(1):47-52. https://doi.org/10.2535/ofaj1936.67.1_47

47. Arlamowska-Palider A. Morphological Studies on the Main Branches of the Radial Nerve in Mammals. Acta Theriologica 1970;15(12):185-197.

48. Guimarães GC, Machado MRF, Santos ALQ, Miglino MA, Cattelan JW. Origem, ramificação e distribuição do nervo radial no braço do gato doméstico (Felis catus domesticus, Linnaeus 1758). Brazilian Journal of Veterinary Research and Animal Science. 2007(44):261-267.

http://dx.doi.org/10.11606/issn.1678-4456.bjvras.2007.26626 